\title{
Major elements of morphological dynamics in the Brahmaputra River
}

\author{
Rajesh Kumar Sah $^{1}$, D. Nagesh Kumar ${ }^{1}$, Apurba Das ${ }^{2}$, and Siddhart Lahiri ${ }^{3}$ \\ ${ }^{1}$ Indian Institute of Science \\ ${ }^{2}$ Tezpur University \\ ${ }^{3}$ Dibrugarh University
}

December 8, 2022

\begin{abstract}
This paper documents the bankline dynamics of the Brahmaputra River along the India and Bangladesh region during the period 1976 to 2018. Multiple approaches, including satellite image-based interpretations, fieldwork, and meta-analysis, are performed to explore the factors responsible for the morphological dynamics of the river. Results suggest that the Brahmaputra River has lost $\sim 2686$ sq. $\mathrm{km}$ of land in the last four decades. Brahmaputra river has also widened $\sim 1.7 \mathrm{~km}$ (mean value over the studied reach) during the period. We identified five active erosional sections along the river. The high erosions along these sections are promoted by the past avulsion and the lowlands areas in the floodplain of Brahmaputra. Interestingly, progressive erosions along the active sections of the Brahmaputra River have been sustained for decades to centuries. Sustained and dominant peripheral second order channels (dominant channels) have largely decided such progressive erosions. Interpretation based on historical maps suggests that the observed morphological changes of the Brahmaputra River are the continuation of the river's recent planform evolution that can be traced back to 2-3 centuries. These rapid morphological changes in Brahmaputra River are conceivably due to high sediment flux, where seismic activities look to be a pragmatic factor.
\end{abstract}

\section{Introduction}

The extant literature on Brahmaputra River dynamics reflects the extensive effort of researchers to comprehend its nature. The lower reach of the Brahmaputra (Jamuna) within Bangladesh is a point of convergence for researchers captivated by its massive avulsion and channel metamorphosis (e.g., Coleman, 1969; Bristow, 1999; Sarker et al., 2014). The present course of Brahmaputra is locally known as Jamuna in Bangladesh and is referred to as the Brahmaputra-Jamuna for the section that lies in Bangladesh. The section within India is referred to as the Brahmaputra throughout this paper. Coleman (1969) considered a pioneer in the field, proposed increased flood discharge, faulting, or a combination of both, triggered the BrahmaputraJamuna channel from the old to the current course. Following this shift, the river exhibited a translatory modification from meandered to braided and erratic behavior in terms of bankline migration. Consequently, Bristow (1987) detailed the channel patterns and migration of Brahmaputra-Jamuna, by sourcing data from Landsat images and historical maps. He deduced that lateral migration with minor channel switching and the Brahmaputra-Jamuna avulsion in Bangladesh are dominant channel movements in the lower reach of the river. Thorne et al. (1993) also focused on erosion and accretion activities of this stretch of the river. They inferred that the severe bank erosion is related to location combined with the spacing of both first order islands and second order bars. Bristow (1999) suggested that avulsion of the Brahmaputra-Jamuna was a result of flow divergence around mid-channel islands, which reoriented the diverted channel into an existing floodplain channel. Khan and Islam (2003) found severe bank erosion and considerable channel widening of the avulsed stretch in Bangladesh. Best et al. (2007) critically examined the avulsion, erosion, structural control, and other aspects associated with floodplain, including the river morphology of 
Brahmaputra-Jamuna. Baki and Gan (2012) used Landsat imageries to conduct short-term and long-term analyses of the migration of the river's course. Sarker et al. (2014) reinforced the earlier works with an indepth morpho-dynamic study of the Brahmaputra-Jamuna River. They highlighted the historical westward migration, significant divergence in left and right (west) bank constituents, diagnosed causal links between drivers, besides morphological responses in time and space.

The Brahmaputra within India was also well studied by various researchers, especially in the last decade (Sarkar et al. , 2012; Sarma and Acharjee, 2018; Saikia et al., 2019). Sarkar et al. (2012) in an erosion and deposition assessment for eighteen years (1990-2008) of Brahmaputra River in Assam (India). Sarma and Acharjee (2018) estimated the braiding index and channel width of Brahmaputra at every 5-minute longitudinal interval within Assam. They found a positive correlation between channel width and braiding index, indicating an increase in braiding index with increasing channel width. In addition to the predominance of erosion, Saikia et al. (2019) credited the enlargement in the Brahmaputra area to the bifurcation of the streams without the loss of land. A good deal of the research has focused on specific stretches of the plains of the Brahmaputra in India, motivated by the ecological and cultural importance of the locale. Brahmaputra River along such specific stretches (e.g., Kaziranga national park, Majuli, and the upper reaches) emerged as stretches of principal interest and research (Kotoky et al., 2003; Sarma and Phukan, 2004; Kotoky et al. , 2005; Sarma, 2005; Sarma and Acharjee, 2012a; Lahiri and Sinha, 2012; Lahiri and Sinha, 2014; Basumatary et al., 2019). Apart from depicting the temporal variation, extent of erosion, and deposition along the stretches under examination, they investigated two major avulsions (Majuli and Lohit), structural and lithological controls, and the after-effects of the earthquake of 1950. Though extensive records support the assessment of Brahmaputra River dynamics, the chronological and regional literature along its length reveal researchers mainly focused either on stretches of interest or on related themes.

The chronic nature of the Brahmaputra River dynamics has engendered further exploration and research into the causative factors. Many researchers underlined structural controls, tectonic and seismic activities as factors that primarily triggered morphological adjustment of Brahmaputra River in the recent past (Morgan and McIntire, 1959; Coleman, 1969; Sarma, 2005; Das and Saraf, 2007; Best et al., 2007; Lahiri and Sinha, 2012; Sarkar et al. , 2012; Sarma and Acharjee, 2012a; Sarker et al., 2014; Lahiri and Sinha, 2014; Sarkar, 2017; Sarma and Acharjee, 2018). Researchers have tried to investigate links between structural controls, avulsion, and bankline dynamics of the river (Winkley et al., 1994; Lahiri and Sinha, 2014). The works of Lahiri and Sinha $(2012,2014)$ introduced seismic stratigraphy and the concept of basin evolution to explain the differential residence time of the Brahmaputra River at different locations. However, seismic activities are primarily linked to changing the rate of sediment supply and the transformation of the Brahmaputra River morphology (Goswami, 1985; Sarker et al., 2014). As far as the lithological aspect is concerned, the floodplains show longitudinal and bank-wise heterogeneity and are often related to the bankline dynamics of Brahmaputra (Kotoky et al., 2003; Sarker et al., 2014; Sarma and Acharjee, 2018). However, two types of nodes viz., permanent and transient are also marked out and noteworthy (Bristow, 1987; Kotoky et al., 2015; Sarma and Acharjee, 2018). The erratic nature of the Brahmaputra and its tributaries often display morphological and fluvial adjustments. Two such activities i.e., avulsion and thalweg migration enhanced morpho-dynamics of Brahmaputra (Sarma and Phukan, 2004; Sarker et al., 2014; Lahiri and Sinha, 2014; Basumatary et al., 2019). Attempts have been made to endorse the role of human interventions as critical factors in morphological changes of the river (Kotoky et al., 2003; Lahiri and Sinha, 2012; Sarker et al. , 2014; Sarma and Acharjee, 2018). The hydro-fluvial processes involved in the shaping and reshaping of Brahmaputra River morphology are widely discussed by the researchers and they are often complementary to each other. Subsidiary channel formation or abandonment, shear failure, bank displacement by liquefaction, cutting, slumping, and piping (activation of an old channel) are interpreted as major processes of the morphodynamical activities of Brahmaputra (Coleman, 1969; Kotoky et al., 2003; Sarma and Phukan, 2004; Sarker et al., 2014; Kotoky et al., 2015; Basumatary et al., 2019).

Previous literature indicates that regional tectonics and basin aggradation have largely decided the recent channel evolution of the Brahmaputra River (Goswami, 1985; Lahiri and Sinha, 2014; Sarker et al., 2014). These triggers control the residential time of the Brahmaputra River or its anabranches at different locations. 
The residential times of major anabranches of Brahmaputra and their angle of approach towards banklines determine the erosional magnitude of their adjacent banks (Coleman, 1969; Basumatary et al., 2019). The varied magnitude of erosional activities along different sections of Brahmaputra shows its preferred erosional sites. To document such spatial patterns, this work constructs an integrated picture of the entire Brahmaputra River dynamics and thereby such erosion-dominant sections of Brahmaputra River are identified. Major driving factors responsible for the erosion along those sections are explored. The residence time and patterns of channel movements of the Brahmaputra River are also discussed to ascertain their migrational behavior.

\section{Study area}

The Brahmaputra is a trans-Himalayan River originating in Angsi Glaciers in western Tibet (Ray et al., 2015). The parent stream from its source flows along southern Tibet as Yarlung Tsangpo. After breaking through the great Himalayan gorge, it enters India and finally descends as Dihang from the mountainous terrain to the Assam valley. During 1915, Dihang was converging with two of its major tributaries Dibang and Lohit, near Kobo (in Assam), to form the Brahmaputra. This confluence point shifted by $\sim 16 \mathrm{~km}$ downstream to Laikaghat in Dhemaji by 1975 and later by 2005, a further downstream shift of $19 \mathrm{~km}$ took place (Lahiri and Sinha, 2012). Presently the confluence is located near Dinjan in Dibrugarh, Assam (Fig. 1). The Brahmaputra flows downstream for about $610 \mathrm{~km}$ in the westerly direction and turns south near Dhubri, Assam, and enters Bangladesh. It continues further south for about $230 \mathrm{~km}$ as the Jamuna before meeting the Ganga (the Padma in Bangladesh) near Goalanda. Das and Saraf (2007) advocated that the sudden southern turn of Brahmaputra near Dhubri is mainly governed by the high land present along the right bank.

The channel reach of Brahmaputra can be divided into three categories: anabranching-cum-braided channel reaches, braided reaches, and narrow single channel reaches (Sarma and Acharjee, 2018). Thorne et al. (1993) described the island reaches as sediment storage zones and the nodal reaches as sediment transmission zones. Morphological adjustment of the river near nodes is explained by Coleman (1969). He mentioned that exaggerated lateral movements of banks above and below a node are common. The nodes along the Brahmaputra River can be deciphered from satellite images (Fig. 1). In India, the nodes are permanent and controlled by hillocks, except at the eastern node where cohesive clay forms the predominant bank material, whereas in Bangladesh, the nodes are transient (Bristow, 1987; Kotoky et al., 2003, Sarma and Acharjee, 2018). Notably, the river has experienced two major re-organizational activities in the form of avulsion near Majuli (Assam) and Gaibandha (Bangladesh) in the $17^{\text {th }}$ and $18^{\text {th }}$ centuries, respectively (Bristow, 1999; Sarma and Phukan, 2004). It is proved that tectonic activities have major roles in reshaping the channel of Brahmaputra (Goswami, 1985; Winkley et al., 1994; Das and Saraf, 2007; Lahiri and Sinha, 2014).

\section{Materials and methods}

This study uses Landsat imageries (MSS, TM, ETM+, and OLI) of the last four decades (1976-2018), mostly at decadal intervals. The image selection strategy is based mainly on the availability of cloud-free data in the region. Post-monsoon satellite imageries are downloaded (from the USGS website) to avoid cloud-content data. Several Landsat images are required to cover the entire Brahmaputra River, which is sometimes nonfeasible due to lack of cloud-free data for a year under evaluation. To overcome such situations, the images of contiguous months of successive years are considered having similar hydrologic conditions (lean phase period). The downloaded imageries are stacked in ERDAS Imagine and finally mosaiced to get a composite image of the entire Brahmaputra River. The composite image is further utilized to digitize the bankline of the Brahmaputra for the study periods.

The ambiguous nature of true bankline identification of the Brahmaputra River is well documented (Hassan et al., 1997; Sarker et al., 2014). Due to complex anabranching, true bankline consideration is always a challenge, where Brahmaputra is concerned. In this study, active anabranches that rejoin the Brahmaputra are considered part of the river, though flanking channels are mostly avoided. Crevasse splay and overbank sediment spills are very common in the Brahmaputra. Such geomorphic traces fade out during the driest periods and are relatively easy to distinguish. Therefore, the satellite images of successive months of the 
relatively dry period are used to differentiate between such geomorphic impressions and true bankline. To reduce the abrupt over or underestimation of bankline dynamics, the delineated banklines of successive study year images are standardized with each other. Further, the banklines of the Brahmaputra utilized for the study periods are digitized (Fig. 2). To document the dynamics of the Brahmaputra River, the entire digitized banklines in Bangladesh and India is divided into equidistant segments. For this purpose, the downstream point where Brahmaputra was confluenced with Ganga (Padma) in 1976 is taken as reference. The river is divided into ten equal reaches, demarcated as R1, R2.. and R10, from reference point to the upstream point of the Brahmaputra, which lies near Laikaghat, and was the area of the concourse of the Dihang, Dibang, and Lohit dating back to 1976 (Fig. 1). Subsequently, the reach-wise comparison is performed to evaluate the land erosion and accretion.

The digitized banklines for study periods are also used to measure the width of the Brahmaputra River. For this purpose, lateral lines at an interval of $\sim 1 \mathrm{~km}$ are drawn for the entire stretch of the river. While drawing the cross-section lines, the orientation of the Brahmaputra River is kept in mind. The cross-sections for river width measurement are drawn perpendicular to the direction of Brahmaputra channel.

This work evaluates the major eroding sections of Brahmaputra. Such active sections are identified based on the severity of erosion along the river. The natures of the erosion, i.e., progressive or random, are interpreted from multi-temporal images. Planform characteristics of Brahmaputra are also interpreted from satellite imageries. It includes identifying the dominant channels, braided and nodal belts, and their nature. The Second order channels, which represent the dominant channels, of Brahmaputra are interpreted based on Bristow's channel hierarchy system (Bristow, 1987; Bristow and Best, 1993). Bristow (1987) described the morphology of Brahmaputra as consisting of first, second, and third order channels. The first order channel comprises the whole river, which may include several second order channels. The second order channel has low stage third order channels within them. This morphological description is used by several researchers working in the Brahmaputra (Thorne et al., 1993; Sarker et al., 2014).

Multiple approaches, including satellite image-based interpretations, fieldwork, and meta-analysis, are performed to evaluate the major drivers of erosion along the active sections of Brahmaputra River. It has inferences from- (a) previous independent research work literature, (b) major seismic activities, (c) floodplain lowlands, and (d) trajectories and sustenance of second order channels near banklines. Shillong and Assam earthquakes of 1897 and 1950 have largely affected the recent channel evolution of Brahmaputra (Oldham, 1899; Goswami, 1985). The possible role of those well-known earthquakes in Brahmaputra River dynamics is discussed. Corona photographs of 1961 are utilized to interpret the effect of the 1950 earthquake along the upper Brahmaputra reaches. It includes identification of sediment lobates ( associated with the earthquake )along the eastern end of Brahmaputra plains. Elevation profiles are drawn using SRTM DEM to identify the lowlands along the floodplains of Brahmaputra. Flow course and the sustenance of the second order channels are identified in ArcGIS to assess their role in erosional activities.

\section{Results and discussion}

4.1 Morphological dynamics of Brahmaputra River in recent decades

Investigation of the short-term dynamics of the Brahmaputra River shows its erosion-dominant nature. The river has eroded nearly $2686 \mathrm{sq}$. $\mathrm{km}$ of land in the last four decades (Table 1). Spatial distinctions have been noticed in the erosional intensity of the reaches of Brahmaputra. The lowermost reaches (viz., R1, R2, and R3) in Bangladesh have suffered high erosion (1240 sq. km). Bank accretion of the Brahmaputra River is significantly low (1226 sq. km) compared to its erosion.

The width of the Brahmaputra River varies from $\sim 1$ to $21 \mathrm{~km}$ along its entire reach, with minimal width at the constricted nodal segment of Guwahati. The river widens to $\sim 21 \mathrm{~km}$ near its entry into Bangladesh. In 1976, the river had an average width of $\sim 8.5 \mathrm{~km}$ (Table 2). Reach-wise analysis reveals that the average width of R3 was the highest followed by R2 and R10 in the year 1976, whereas the lowest width was in R6. In 1988, the river's width increased substantially, with an average increase of $\sim 1 \mathrm{~km} /$ reach, taking the width close to $9.5 \mathrm{~km}$. The trend continued in the subsequent decade with an increase of $\sim 0.5 \mathrm{~km}$. However, the 
trend slowed down in the recent decades (2008 and 2018), and the present average width of the Brahmaputra River stands at $10.2 \mathrm{~km}$ (Table 2). Three classified reaches viz., R1, R3, and R5 experienced large expansions in their width with an average widening of $\sim 4.1,3.7$, and $2.1 \mathrm{~km}$, respectively. Figure 3 summarizes the progressive increase of Brahmaputra River width in recent decades.

Along the entire reach of Brahmaputra, the least bankline dynamics were observed at the nodal segments. There are six major nodes $\left(\mathrm{N}_{1}-\mathrm{N}_{6}\right)$ identified in the images of 2018 (Fig. 1). Two of them are in Bangladesh and four in India. The nodes in Bangladesh are located near Sirajganj $\left(\mathrm{N}_{1}\right)$ and Madarganj $\left(\mathrm{N}_{2}\right)$. Similar corresponding nodes can be traced back to earlier work (Thorne et al., 1993; Sarker et al., 2014). Moreover, the shifting and migration of the nodes in Bangladesh are well documented (Thorne et al., 1993). In this study, $\mathrm{N}_{1}$ showed a relatively gradual widening in the initial decade (1976-1986), followed by a significant widening between 1987-1995; but bridge construction imposed restrictions in the subsequent period. The right bank distributary downstream to the bridge is virtually abandoned and is likely to extend the length of the nodal segment in the future. The transient node $\mathrm{N}_{2}$ is confined to its left bank and showed some intra-decadal alteration in width and small-scale migration during the study period. Out of four nodes in India, two $\left(\mathrm{N}_{3}\right.$ and $\left.\mathrm{N}_{4}\right)$ are restricted by hard gneissic rocks (Sarma and Acharjee, 2018) near Goalpara and Guwahati. The third node $\left(\mathrm{N}_{5}\right)$, near Tezpur, is again restricted by hard rock hills on its left bank. During the study period, restricted migration of the $\mathrm{N}_{5}$ is noticed, and the present position of the node is a result of the migration of the dominant channel towards the left bank, which is the hilly section and constricts any erosional activity. The fourth node $\left(\mathrm{N}_{6}\right)$ is bounded by cohesive clay material near Salmora (Kotoky et al., 2003). The existence of $\mathrm{N} 6$ can be traced back nearly a century with very gradual erosion activity that underscores its continued existence.

\subsection{Major eroding sections of Brahmaputra River}

Five major sections of the Brahmaputra River have been identified which have suffered high erosion in the last four decades. Those active sections lie in the Brahmaputra River's lower, middle, and upper divisions. Researchers focusing on different sections of Brahmaputra have also depicted similar sides of active erosion (Sarkar et al., 2012; Sarker et al., 2014; Lahiri and Sinha, 2014).

The lower active section lies in Bangladesh. Brahmaputra-Jamuna, along this section, has gone through both erosion and accretion during the study period. This section has shown the dominance of bank erosion and channel widening. This shift is evident in the entire lower section, though the magnitude at different reaches varies. Interestingly, the intense land loss is noticed only during the study period's initial decades (1976-1998), which contributed to a net land loss of around $678 \mathrm{sq.} \mathrm{km} \mathrm{(Table} \mathrm{1).} \mathrm{As} \mathrm{far} \mathrm{as} \mathrm{the} \mathrm{dominant}$ process of land loss is concerned, progressive bank cutting predominates along the right bank, while both progressive and alternate bank dynamics characterize the left bank (R1 and R2). The relatively random nature of left bank dynamics is related to the rapid activation and abandonment of braided channels triggered by flowing-channel repositioning (Fig. 4). It is important to note that the life span of eroding bends on the right bank is higher compared to the left bank (Sarker et al., 2014), which promotes the random nature of the left bank dynamics.

Two active sections in the middle division of the Brahmaputra River lie near the confluence of Manas and the upstream of Guwahati. The bankline of Brahmaputra has migrated as high as nearly $5 \mathrm{~km}$ near the confluence of Manas. Long-term assessment based on older toposheets clearly shows a sustained erosion along the section for almost a century. Extensive erosion near Manas confluence has engulfed several villages (e.g., Mainbari, Kubanbari, and Chenglidiya) and threatened the existence of Baghbor hill. The hill may become an island with continued erosion along the section (Fig. 5). The active section upstream to Guwahati lies on the left bank of Brahmaputra. The aggressive nature of the river along the section has eroded $181 \mathrm{sq}$. km of land from 1976 to 2018. It has swallowed several villages (e.g., Salmari, Sialmari, and Leruamukh). The rate of land loss along the section is nearly $4.3 \mathrm{sq} . \mathrm{km} /$ year, which is significant as the floodplain dwellers largely depend on the meager assets.

The other two active sections along the upper Brahmaputra division lies near the confluences of Subansiri 
and Lohit. Massive erosion near the confluence of Subansiri has significantly reduced the landmass of the Majuli river island. The western end of Majuli is sandwiched between Subansiri and Brahmaputra rivers, and therefore any oscillation of the rivers' banklines have a significant effect on ever reducing landmass of the island. The left bank of the Brahmaputra near the present confluence of Lohit is continuously drifting towards southern floodplains. The shift of the river bankline has resulted in a land loss of around $99 \mathrm{sq} . \mathrm{km}$ in the last four decades. Progressive bank cutting is the dominant process of erosion along the section.

\subsection{Major drivers}

The lower section of the Brahmaputra-Jamuna is identified as the most dynamic stretch, which is mostly active in the initial decades (1976-1998). The present course of Brahmaputra-Jamuna is a consequence of the avulsion that started between 1828-1843 (Bristow, 1999). The avulsion began diversion of flow to Brahmaputra-Jamuna channel and gradual evolution of the new channel from meandering to a braided one. The wide alteration in Brahmaputra-Jamuna reach is part of the post-avulsion planform evolution of the river. It is also emphasized that the efforts to stabilize the bankline through engineered structures may have contributed to the decreasing trend of land loss in recent decades (Sarker et al., 2014). Yet, the role of engineering structures cannot be denied in the decreasing trend of land loss. But the quality of embankments and their effectiveness along the lower reach have remained questionable (Hossain et al., 2008; Hossain et al., 2011), and therefore its greater role in bank erosion reduction is open to further debate. In this regard, the dynamic equilibrium of Brahmaputra-Jamuna and its channel evolution (Coleman, 1969; Sarker and Thorne, 2006; Takagi et al., 2007) is more decisive. Takagi et al . (2007) noted that the river had switched to dynamic equilibrium in the late 1990s. The evolved reach of Brahmaputra-Jamuna is attaining equilibrium with its contiguous upper reaches. It has resulted in a relatively efficient widened channel that receded the morphological dynamics of the Brahmaputra-Jamuna River.

Observation of the Brahmaputra bankline near the confluence of Manas shows its active erosional nature. The positions of second order channels have played a significant role in massive land loss near the confluences. Along the stretch, Das and Saraf (2007) noted the strengthening of the anabranching channel along the northern edge of the Shillong plateau. They attributed the changes along the section to be due to the tectonic activity of the Shillong plateau, most likely the 1987 earthquake. Sarkar et al. (2012) opined that developed lowlands along fault affected plateau edge triggering the river to respond. We observed that the Brahmaputra is eroding the northern bank near Manas confluence along the active stretch. The massive erosion indicates a possible depression formed along the north edge of the Brahmaputra near Manas confluence. Bilham and England (2001) demonstrated the pop-up of the Shillong plateau during the 1897 Assam earthquake. The post-effect of the earthquake is always a concern for the researchers (Das and Saraf, 2007; Lahiri and Sinha, 2014). Lahiri and Sinha (2014) explained the continuation of the pop-up phenomenon and its effect on subsidence near Majuli. The rapid erosion along the stretch is a reaction to the 1897 earthquake, which formed a depression along the northern edge of the Brahmaputra River. It should be noted that the river channel along the active stretch was narrow and mostly confined to the southern part in the past.

The left bank of Brahmaputra upstream of Guwahati has inexorably migrated towards floodplains in the last four decades. The flood map shows that the floodplain adjacent to the eroded side is lowland and among the region's most frequently inundated areas. The lowland has prompted migration and sustained second order channel along the left bank. And the induced greater fluvial pressure eroded the bankline along the stretch. Therefore, the position of the channel along the lowland floodplain is consistently eroding the southern bank of this middle reach. Shear failures are a common cause of erosion as the second order channel continuously hugging the left bank of Brahmaputra along the active section.

The massive land loss near the confluence of Subansiri is due to the widening of the Brahmaputra as well as its tendency of switching towards the north. The widening and northward shift of the channel near the tail end of Majuli has captured the earlier course of Brahmaputra (Luit/Subansiri). The Brahmaputra expanded along the floodplains of Luit/Subansiri, which was naturally a lowland. A prominent elevation low can be noticed in the northwest of Brahmaputra-Subansiri confluence (Fig. 6a and b). It lies below the Dafla hill 
blocks (DHB), a Siwalik fold belt. Das (2004) remarked that DHB is in the quiescence period and less active (earthquake) relative to other areas of the region. However, he insisted that the area may undergo brittle failures in the future. DHB is also affecting the course of Brahmaputra (Das and Saraf 2007). The river channel between Kaziranga and Brahmaputra-Subansiri confluence follows the southward Siwalik fold of DHB. It demonstrates the dominance of DHB in floodplain topography along the stretch and, therefore, looks to be a leading factor in the development of elevation low along the northwest of Brahmaputra-Subansiri confluence. This subsidence is contributing to the orientation of the flow of Brahmaputra towards the north bank resulting in the massive erosion near the Subansiri confluence.

The Brahmaputra has widened drastically along the present confluence of Lohit and progressively migrated towards the south. It is suggested that the erosion is triggered by the avulsion of Lohit (Borgohain et al., 2016). Sarma and Acharjee (2012b) interpreted that the subsided area on the north of Oakland-Guijan scarp (fault) developed due to the great earthquake of Assam is causing the bank erosion. The comparison with older maps clearly shows the river has expanded considerably on both sides to accommodate the large sediment released during the later periods of the 1897 earthquakes and the Assam earthquake of 1950. Corona photograph of 1961 shows the large sedimentation along the eastern front of the Brahmaputra related to the well-known 1950 earthquake (Fig. 7). Similarly, Sah et al. (2022) identified sand splay deposits (associated with the earthquake) along the foothill region of Jiadhal-Dikari belt using the Corona photograph. The massive sedimentaion along the eastern front has affected the morphology of the Brahmaputra River. The elevation profile along the cross-section of Lohit near its Brahmaputra confluence shows a belt of low land along the corridor of the Dibru river (Fig. 8a and b). The elevation might be affected by vegetation in the northeastern corner, but overall it shows an elevation low belt along the Dibru river corridor. Prominent migration of Brahmaputra left bank along the corridor of Dibru river is discernable. A similar lowland is identified by Sarma and Acharjee (2012b), which was inferred based on the increase in the amount of lowland between 1916 to 1963. The lowland encouraged the thalweg position of Brahmaputra near the left bank and promoted progressive bank erosion along the stretch. The temporary imbalance generated from the shifted flow of Lohit to the Brahmaputra is supplemented to the bankline erosion.

\subsection{The role of second order channels in bank erosion of Brahmaputra River}

The position of second order channels essentially controls the erosional and accretion activities of Brahmaputra. The sustained currents of second order channels erode the non-cohesive bank of braided sections of Brahmaputra continuously. The trajectories of such channels also depend on the flow orientation of channels immediately upstream and the position and orientation of islands. Due to the basin's aggradational nature, continuous alteration in local bed slope and roughness along cross-sections of Brahmaputra is common. It affects the channels of all magnitudes of the Brahmaputra River. The aggradation causes the main channel of Brahmaputra to seek better gradients, new alignments, and a path of least resistance (Coleman, 1969). Several second order channels of Brahmaputra have preferred a certain path for decades. It ascertains that few channels maintain their efficiency despite heavy sedimentation by routine seasonal bed scour. This is mainly because of high discharge along the preferred channel. Local factors are decisive in the long sustenance of a channel. It includes lateral slope, position, and orientation of the contiguous islands, flow orientation of immediate upstream, and confluences with major tributaries. Such sustained and preferred second order channels have caused progressive bankline migrations in Brahmaputra which have been noticed in the major eroding sections in the Brahmaputra. The magnitude and sustenance of a second order channel largely decide shear stress on the adjacent bankline and its susceptibility towards erosion.

\subsection{Summary}

The morphological dynamics of the Brahmaputra River indicate its rapid planform evolution in the last four decades. The river width increased by nearly $1.7 \mathrm{~km}$ (mean value over the studied reach) during the period. Looking at the historical maps of Renell (1776), Wilcox (1830), and Butler (1847), we can decipher that a few centuries back Brahmaputra River was less braided with meandering stretches. It suggests that the observed morphological change of the Brahmaputra River is the continuation of the recent planform evolution of the river that can be traced back to 2-3 centuries. Such river morphological adjustments are 
often related to the sediment bedload, its transport, and the proportions of bedload and suspended load in a river (Schumm, 1963; Smith and Smith, 1984; Church, 2006). Taking the example of the recent massive earthquake (1950 Assam earthquake), researchers proved that high sediment release after the earthquake had affected the morphology of the Brahmaputra River (Goswami, 1985; Sarker and Thorne, 2006; Sarker et al., 2014). The rapid morphological changes in Brahmaputra River are conceivably due to high sediment flux, where seismic activities look to be a pragmatic factor.

\section{Conclusion}

The principal conclusions from this study can be summarized as-

- This study on the short-term dynamics of the Brahmaputra River shows its erosion-dominant nature with an overall channel widening of $\sim 1.7 \mathrm{~km}$ in the last four decades. Erosion and accretion are dominant in braided sections of the Brahmaputra River, while it is limited in nodal sections.

- There are five stretches- lying in lower, middle, and upper reaches- identified as the most dynamic sections of the Brahmaputra during the study period. The lower active stretch lies in Bangladesh and impacts both banks along Brahmaputra-Jamuna. Two active stretches in the middle Brahmaputra division lie near the confluence of Manas on the right bank and along the upstream of Guwahati on the left bank. The remaining two active stretches lie in the upper reaches near the confluence of Subansiri and Lohit tributaries.

- Brahmaputra-Jamuna is identified as the most dynamic stretch which is mostly active in the initial decades (1976-1998). A trend of decreased bank erosion in the Brahmaputra-Jamuna during recent decades is noticed, attributed to relatively efficient channel evolution over time.

- The active sections in the middle and upper divisions of Brahmaputra are promoted by lowland areas in the floodplain and rapid bed aggradation.

- Sustained and dominant second order channels have largely decided the intense erosion in major eroding sections of Brahmaputra.

- The observed morphological change of the Brahmaputra River is the continuation of the recent planform evolution of the river that can be traced back to 2-3 centuries where seismically induced high sedimentation looks to be a dominant trigger.

\section{Acknowledgements}

The first Author is an awardee of the Council of Scientific and Industrial Research (CSIR) research associateship [HRDG(CSIR) sanction letter no./file no.: 09/079(2836)2019-EMR-I]. The author acknowledges CSIR for the same. The authors would like to thank Dr. G. Maitra, Tezpur University for checking the manuscript. The authors gratefully acknowledge the United States Geological Survey (USGS) as the source for Landsat, Sentinel, and SRTM DEM data. Interpretations are made from the flood hazard map of Assam prepared by the National Remote Sensing Centre (NRSC), ISRO, Govt. of India. We acknowledge NRSC for the same.

\section{References}

Baki, A.B.M., \& Gan, T.Y. (2012). Riverbank migration and island dynamics of the braided Jamuna river of the Ganges-Brahmaputra basin using multi-temporal Landsat images. Quaternary International , 263, 148-161. doi:10.1016/j.quaint.2012.03.016

Basumatary, H., Sah, R.K., \& Das, A.K. (2019). Analyzing area dynamics on a protected floodplain using long-term sequential data: the case of Kaziranga national park. Journal of the Indian Society of Remote Sensing , 47 (9), 1557-1566. doi.org/10.1007/s12524-019-01000-х

Best, J.L., Ashworth, P.J., Sarker, M.H., Roden, J.E. (2007). The Brahmaputra-Jamuna river, Bangladesh. In: Gupta, A. (Ed), Large rivers: geomorphology and management . Chichester, Wiley, pp. 395-433.

Bilham, R., \& England, P. (2001). Plateau 'pop-up' in the great 1897 Assam earthquake. Nature , 410, 806-809. 
Borgohain, S., Das, J., Saraf, A.K., Singh, G., Baral, S.S.( 2016). Morphodynamic changes of Lohit river, NE India: GIS-based study. Current Science, 110 (9), 1810-1816. doi: 10.18520/cs/v110/i9/1810-1816

Bristow, C.S. (1987). Brahmaputra river: channel migration and deposition. In: Ethridge, F.G., Flores, R.M., \& Harvey, M.D. (Eds), Recent development in fluvial sedimentology . SEPM (Special Publication) 39, pp. $63-74$.

Bristow, C.S., \& Best, J.L. (1993). Braided rivers: perspectives and problems. In: Best, J.L. \& Bristow, C.S (Eds), Braided rivers. Geological Society London Special Publications, 75, pp. 1-11.

Bristow, C.S. (1999). Gradual avulsion, river metamorphosis and reworking by underfit streams: a modern example from the Brahmaputra river in Bangladesh and a possible ancient example in the Spanish Pyrenees. In: Smith, N.D. \& Rogers, J. (Eds), Fluvial sedimentology VI . Special Publication, International Association of Sedimentologists, 28, pp. 221-230.

Butler, J. (1847). A sketch of Assam with some account of the hill tribes, by an officer. London, Smith elder \& Co.

Church, M. (2006). Bed material transport and the morphology of alluvial river channels. Annual Review of Earth and Planetary Sciences, 34, 325-354

Coleman, J.M. (1969). Brahmaputra river: channel processes and sedimentation. Sedimentary Geology , 3, 129-239. doi: 10.1016/0037-0738(69)90010-4

Das, J.D. (2004). Active tectonics of the Eastern Himalayan foothills region and adjoining Brahmaputra basin based on satellite images.International Journal of Remote sensing , 25 (3), 549-557. doi: $10.1080 / 0143116031000148070$

Das, J.D., \& Saraf, A.K. (2007). Technical note: remote sensing in the mapping of the Brahmaputra/Jamuna river channel patterns and its relation to various landforms and tectonic environment.International Journal of Remote Sensing , 28 (16), 3619-3631. doi: 10.1080/01431160601009664

Goswami, D.C. (1985). Brahmaputra river, Assam, India: physiography, basin denudation and channel aggradation. Water Resources Research , 21, 959-978. doi.org/10.1029/WR021i007p00959

Hassan, A., Huque, I., Huq, P.A.K., Martin, T.C., Nishat, A., \& Thorne, C.R. (1997). Defining the banklines of Brahmaputra-Jamuna river using satellite imagery. Stellenbosch, South Africa, 3rd International Conference on River Flood Hydraulics, 349-354.

Hossain, M.B., Sakai, T., \& Hossain, M.Z. (2011). River embankment and bank failure: a study on geotechnical characteristics and stability analysis. American Journal of Environmental Sciences , 7 (2), 102-107.

Hossain, Z., Islam, Z., \& Sakai, T. (2008). An investigation on failure of embankments in Bangladesh. Arlington, VA, USA: International Conference on Case Histories in Geotechnical Engineering, 1-7.

Khan, N.I., \& Islam, A. (2003). Quantification of erosion patterns in the Brahmaputra-Jamuna river using geographical information system and remote sensing techniques. Hydrological Processes , 17, 959-966. doi: 10.1002/hyp. 1173

Kotoky, P., Bezbaruah, D., Baruah, J., \& Sarma, J.N. (2003). Erosion activity on Majuli - the largest river island of the world.Current Science, 84, 929-932.

Kotoky, P., Bezbaruah, D., Baruah, J., \& Sarma, J.N. (2005). Nature of bank erosion along the Brahmaputra river channel, Assam, India.Current Science , 88 (4), 634-640.

Kotoky, P., Bezbaruah, D., \& Sarma, J.N. (2015). Spatio-temporal variations of erosion-deposition in the Brahmaputra river, Majuli-Kaziranga sector, Assam: implications on flood management and flow mitigation. In: Ramkumar, M., Kumaraswamy, K., \& Mohanraj, R. (Eds), Environmental management of river basin ecosystems . Berlin, Springer, pp.227-251. 
Lahiri, S.K., \& Sinha, R. (2012). Tectonic controls on the morphodynamics of the Brahmaputra river system in the upper Assam valley, India. Geomorphology , 169-170, 74-85. doi: 10.1016/j.geomorph.2012.04.012

Lahiri, S.K., \& Sinha, R. (2014). Morphotectonic evolution of the Majuli island in the Brahmaputra valley of Assam, India inferred from geomorphic and geophysical analysis. Geomorphology , 227, 101-111. doi: 10.1016/j.geomorph.2014.04.032

Morgan, J.P., \& McIntire, W.C. (1959). Quaternary geology of the Bengal basin, east Pakistan and India. Bulletin of The Geological Society of America , 70, 319-342.doi: 10.1130/00167606(1959)70[319:QGOTBB]2.0.CO;2

Oldham, R.D. (1899). Report on the Great Earthquake of 12th June 1897. Memoirs of the Geological Survey of India , 29, Calcutta.

Ray, P.A., Yang, Yi-Chen E., Wi, S., Khalil, A., Chatikavanij, V., \& Brown, C. (2015). Room for improvement: hydroclimatic challenges to poverty-reducing development of the Brahmaputra river.Environmental Science \&3 Policy , 54, 64-80. doi: 10.1016/j.envsci.2015.06.015

Rennell, J. (1776). An actual survey of the Provinces of Bengal, Bahar \&c. by major James Rennell, Engineer, Survey General to the Honourable the East India Company. Published by Permission of the Court of Directors, from a drawing in their possession; by A. Dury.

Sah, R.K., Kumar, D.N., \& Das, A.K. (2022). Avulsion distribution on rivers in the Himalayan foreland region. Hydrological Sciences Journal. doi: 10.1080/02626667.2022.2136000

Saikia, L., Mahanta, C., Mukherjee, A., \& Borah, S.B. (2019). Erosion-deposition and land use/land cover of the Brahmaputra river in Assam, India. Journal of Earth System Science, 128, 211(1-12). doi: 10.1007/s12040-019-1233-3

Sarkar, A. (2017). Brahmaputra river bank failures-causes and impact on river dynamics. In: Mikoš, Matjaž, Vilímek, Vít, Yin, Y., \& Sassa, K. (Eds), Advancing culture of living with landslides . Springer International Publishing AG, 273-280.

Sarkar, A., Garg, R.D., \& Sharma N. (2012). RS-GIS based assessment of river dynamics of Brahmaputra river in India. Journal of Water Resource and Protection , 4, 63-72. doi: 10.4236/jwarp.2012.42008

Sarker, M.H., \& Thorne, C.R. (2006). Morphological response of the Brahmaputra-Padma-Lower Meghna river system to the Assam earthquake of 1950. In: Smith, G.H.S., Best, J.L., Bristow, C.S. \& Petts, G.E. (Eds),Braided rivers: process, deposits, ecology and management . International Association of Sedimentologists Special Publication, 36, Blackwell Publishing, 289-310.

Sarker, M.H., Thorne, C.R., \& Aktar, N. (2014). Morpho-dynamics of the Brahmaputra-Jamuna river, Bangladesh. Geomorphology , 215, 45-59. doi: 10.1016/j.geomorph.2013.07.025

Sarma, J.N., \& Acharjee, S. (2012b). Bank erosion of the Brahmaputra river and neotectonic activity around Rohmoria Assam, India.Comunicações Geológicas , 99, 33-38.

Sarma, J.N. (2005). Fluvial process and morphology of the Brahmaputra river in Assam, India. Geomorphology , 70, 226-256. doi: 10.1016/j.geomorph.2005.02.007

Sarma, J.N., \& Acharjee, S. (2012a). A GIS based study on bank erosion by the river Brahmaputra around Kaziranga national park, Assam, India.Earth System Dynamics Discussions , 3, 1085-1106. doi: 10.5194/esdd3-1085-2012

Sarma, J.N., \& Acharjee, S. (2018). A study on variation in channel width and braiding intensity of the Brahmaputra river in Assam, India.Geoscience, 8 (9), 343(1-19). doi: 10.3390/geosciences8090343

Sarma, J.N., \& Phukan, M.K. (2004). Origin and some geomorphological changes of the river island Majuli of the Brahmaputra in Assam, India.Geomorphology , 60, 1-19. doi: 10.1016/j.geomorph.2003.07.013 
Schumm, S.A. (1963). Sinuosity of alluvial rivers on the great plains. Geological Society of America Bulletin , 74, 1089-1100. 10.1130/0016-7606(1963)74[1089:SOAROT]2.0.CO;2

Smith, N.D., \& Smith, D.G. (1984). William River: An Outstanding Example of Channel Widening and Braiding Caused by Bed-Load Addition.Geology , 12, 78-82.

Takagi, T., Oguchi, T., Matsumoto, J., Grossman, M.J., Sarker, M.H., \& Matin, M.A. (2007). Channel braiding and stability of the Brahmaputra River, Bangladesh, since 1967: GIS and remote sensing analyses.Geomorphology , 85, 294-305. doi:10.1016/j.geomorph.2006.03.028

Thorne, C.R., Russell, P.G., \& Alam, M.K. (1993). Planform pattern and channel evolution of the Brahmaputra river, Bangladesh. In: Best, J.L., \& Bristow, C.S. (Eds), Braided rivers . Geological Society London Special Publications, 75, pp. 257-276.

Wilcox, R. (1830). Map of the countries showing the sources of Irawadi river and the eastern branch of Brahmaputra comprising Assam and Manipur the hilly districts of the Singphos part of Sham and of the Chinese provinces of Yun-nan and Thibet. Reduced from a copy of the original map by Lieutenant R. Wilcox on 16n miles to an inch, in the Surveyor general's office Calcutta. Published in Asiatic researches 17 (in 1832).

Winkley, B.R., Lesleighter, E.J., \& Cooney, J.R. (1994). Instability problems of the Arial Khan river, Bangladesh. In: Schumm, S.A., \& Winkley, B.R. (Eds), The variability of large alluvial rivers . New York, ASCE Press, American Society of Civil Engineers, pp.269-284.

\section{Figure legends:}

Figure 1. The classified reaches of Brahmaputra River. For this demonstration, 2019 greyscale image of Sentinel 2 (VNIR channel) is used in the background.

Figure 2. Bankline dynamics of Brahmaputra River during 1976-2018 in: (a) lower, (b) middle and (c) upper divisions.

Figure 3. River width of Brahmaputra during 1976, 1988, 1998, 2008 and 2018.

Figure 4. The processes of bankline dynamics in the Brahmaputra-Jamuna River.

Figure 5. High erosion near Manas-Brahmaputra confluence which has threatened the existence of Baghbor hills.

Figure 6. (a) Cross section (AA/) along the downstream of Brahmaputra-Subansiri confluence; and (b) elevation profile along $\mathrm{AA}^{/}$showing a lowland area low in the northwest of Brahmaputra-Subansiri confluence.

Figure 7. Corona photograph of the year 1961. Sediment lobates (circled area in the photograph) along the eastern end of Brahmaputra plains can be noticed in the photograph.

Figure 8. Map showing: (a) Lowland corridor of Dibru river and cross section $\mathrm{CC}^{/}$and (b) elevation profile across Dibru river lowland corridor.

\section{Hosted file}

Figures.docx available at https://authorea.com/users/461837/articles/557434-major-elementsof-morphological-dynamics-in-the-brahmaputra-river

\section{Hosted file}

Tables.docx available at https://authorea.com/users/461837/articles/557434-major-elementsof-morphological-dynamics-in-the-brahmaputra-river 